ВОРОНЕЖСКОЕ КРАЕВЕДЕНИЕ

\title{
Родники Шипова леса
}

\author{
В. И. Федотов \\ Воронежский государственный университет, Российская Федераиия \\ (394018, г. Воронеж, Университетская пл., 1)
}

\begin{abstract}
Аннотация: Цель - познакомить географическую общественность и лесоводов Воронежской области с изменением обводненности лесных ландшафтов региона на примере Шипова леса за последние 160-170 лет.

Mатериаль и методы. В статье использованы опубликованные материалы в «Лесном журнале» (1887) и полевые наблюдения автора.

Результатьл и обсуждения. Установлено, что за последние 150-170 лет в Шиповой дубраве на границе лесостепи и степи происходили неоднократные периоды обводненности. Периоды высокого стояния уровня грунтовых вод, выражающиеся в обилии выходов родников, чередовались с периодами дефицита верховодки и как следствие истощения родников.

Заключение. Родниковые воды Шипова леса - хороший индикатор, с помощью которого можно объяснить естественное произрастание дубравы на северной границе степи.
\end{abstract}

Ключевые слова: Шипов лес, родники, дебит, обводненность, морена.

Для цитирования: Федотов В. И. Родники Шипова леса// Вестник Воронежскогогосударственного университета. Серия: География. Геоэкология, 2021, № 1, с. 65-68. DOI: https://doi.org/10.17308/ geo.2021.1/3257

\section{ВВЕДЕНИЕ}

На пространствах лесостепи и степи Русской равнины в относительно хорошем состоянии сохранности три массива дубрав - Тульские засеки (Тульская область), Черный лес (Кировоградская область Украины) и Шипов лес (Воронежская область).

Шипова дубрава стала широко известна со времени строительства морского флота на верфях рек Донского бассейна. Петр Великий после посещения Шипова леса назвал его образно - «золотым кустом государства российского». Действительно в начале XVIII века древесина дубравы широко использовалась на Павловских корабельных верфях. Лес неоднократно в результате интенсивной эксплуатации вырубался. Сегодняшние насаждения - порослевая генерация.

Шипов лес (Шиповское опытное лесничество) - экспериментальная площадка, где разрабатывались методы восстановления семенных дубрав.
Цель нашего исследования заключается в том, чтобы познакомить географическую научную общественность и лесоустроителей региона с динамикой обводненности Шиповой дубравы.

\section{МАТЕРИАЛЫ И МЕТОДЫ}

В статье использованы опубликованные материалы в «Лесном журнале» в конце XIX столетия и натурные наблюдения на территории Шиповского лесничества в XX веке.

\section{РЕЗУЛЬТАТЫ И ОБСУЖДЕНИЯ}

Обводнение Шипова леса - особая тема в познании особенностей природы. Д. Кравчинский в статье «Исторический и лесоводственный очерк Шипова леса Воронежской губернии», опубликованной во 2 и 4 номерах Лесного журнала за 1887 год со ссылкой на материалы лесоустройства 1846 года пишет следующее: «Топей, мочажин, болот и вообще сырых мест в Шиповой роще очень мало, но и те находятся при руслах небольших овражных протоков. Даже после самого сильно-

(С) Федотов В.И., 2021

$\triangle$ Федотов Владимир Иванович, e-mail: deanery@geogr.vsu.ru

(c) (i) Контент доступен под лицензией Creative Commons Attribution 4.0 License. 
го ливня и теперь следов переувлажнения в лесу не встретить. Лесная подстилка и рыхлая комковатая почва всасывают влагу как губка. Вода, если и задерживается, то только на укатанных тяжелым транспортом лесных дорогах.

Однако было время, когда водных источников в Шиповом лесу было значительно больше. Лесоустроители середины XIX века отмечали значительное количество родников, протоков и ручьев. В Первой и Второй Корабельных дачах из 37 «стражничьих лесов» (кордонов) 22 находились вблизи ручьев и родников, которые были единственными здесь естественными источниками питьевой воды». Ниже приведен перечень кордонов с указанием находившихся вблизи них источников по материалам лесоустройства 1846 года.

Первая Корабельная дача

1. Полянский - родник в 40 саженях ${ }^{1}$.

2. Кочковатый $-1 / 2$ версте 2 .

3. Ямной - ручей.

4. Бочаров - ручей в 60 саженях.

5. Итрогский 1-й - родник в 150 саженях.

6. Кабульский - ручей в 100 саженях.

7. Большая Яруга - родник в 200 саженях.

8. Форпостный - ручей.

9. Комов - ручей.

10. Толстой - в 170 саженях.

11. Давыдов - родник в $1 / 2$ весрте.

12. Итрогский 2-й - ручей в $1 / 2$ версте.

13. Дегтяной - родник в 100 саженях. Вторая Корабельная дача

14. Верхне-Моховой - родник.

15. Тумановский - родник.

16. Чернавский - родник.

17. Камышеватый - ручей Мельничный.

18. Кирпичный - родник Чернецкий.

19. Новенький - ручей Водяной.

20. Богатый - ручей Богатый.

21. Петровский - родник Попов.

22. Михайловский - ручей в 100 саженях.

Спустя 40 лет, ситуация с обводнением Шипова леса разительно меняется. Как пишет Д. Кравчинский (1887), «непересыхающих ручьев и родников по всей площади Шипова леса не имеется вовсе. Стража получает воду исключительно из колодцев, причем из 14, вырытых по границе южной дачи, только в 3-х, расположенных на западной границе леса и на самой южной его окраине, уровень зимней и летней воды колеблется в пределах 5-15 аршин ${ }^{3}$, в остальных же он изменяется между 15 и 24 аршинами».

Такое резкое за столь короткое время снижение водности в Шиповой дубраве во второй половине XIX века трудно объяснить. Не исключено, что это было связано с некоторым снижением в то время количества атмосферных осадков.

Сегодня ситуация с обводнением совершенно иная. В устьях ряда логов, выходящих из Шипова леса, построены рукотворные накопители влаги пруды. По периферии леса и его опушках встречаются известные далеко в округе родники.

Чернавский родник. На высоком косогоре над Осередью посреди густого зеленого массива Шипова леса приютилось небольшое по воронежским меркам село Чернава. На юго-западной околице села лес расступается, оставляя место степному травостою. Между стеблей красочного разнотравья просматривается узкая змейка натоптанной тропинки, спускающейся к подножью склона. Каждодневно и в летний зной, и в ветреную зимнюю стужу осторожно спускаются по ней жители Чернавы. Вниз они идут с пустыми, а вверх поднимаются с полными ведрами родниковой воды. Отказаться от этого нелегкого многовекового «обряда» ходить за питьевой водой к роднику, не помогло даже сооружение в селе водопровода.

Чернавский родник - широко известное в округе место. Впервые пришедшему к роднику человеку бросаются в глаза массивные чурбаны-сидения и сбитые дощатые столы, отодвинутые в тенистые заросли из ив. Лесничий Николай Тимофеевич говорит, что у местных жителей становится традицией собираться у Чернавского родника в дни пристольных праздников, знатных юбилеев и по случаю иных торжеств. Утоляя жажду чистой, как слеза, студеной водой, вспоминаются здесь бессмертные слова военного летчика, писателя-гуманиста Антуана де Сент-Экзюпери: «Вода! У тебя нет ни вкуса, ни цвета, ни запаха, тебя не опишешь, тобой наслаждаешься не понимая, что ты такое. Ты не просто необходима для жизни, ты и есть жизнь. С тобой во всем существе разливается блаженство, которое не объяснить только нашими пятью чувствами. Ты нам возвращаешь силы и свойства, на которых мы уже поставили было крест. Твоим милосердием снова отворяются иссякшие родники сердца».

\footnotetext{
${ }^{1}$ Сажень - русская мера длины, равная 2,13 м.

${ }^{2}$ Верста - русская мера длины, равная 1,06 км.

${ }^{3}$ Аршин - русская мера длины, равная 0,71 м.
} 
Чернавский родник образуют восемь струй, веером рассредоточенные вдоль подножья склона. В месте выхода на дневную поверхность подземной воды склон принимает форму амфитеатра. Каждая струя заключена в сооруженные деревянные колодцы - накопители. А уже затем из этих неглубоких емкостей вода едва заметными струйками течет в направлении днища. Вдоль колодцев проложен деревянный настил, огороженный со стороны низины перилами.

Суммарный дебит всех восьми струй родника не превышает 1,5-2 литров в секунду. Самый крупный по размеру и дебиту струй колодец-накопитель находится ближе к тальвегу лога. Сверху он прикрыт навесом, под которым установлен деревянный православный крест и несколько миниатюрных икон. За Чернавским родником давно закрепилась молва родника-целителя.

Не меньшей известностью в селах вдоль Осереди пользуется Крепацкая криница на правобережье реки против села Александровка Павловского района. Криница находится в устье балки Княжья, которая своим верховьем прячется в зарослях Шипова леса. Крепацкая криница - единственное в Воронежской области место, где подземная вода изливается из глубокого разлома в толще писчего мела. Родник относится к типу напорных источников. Место выхода воды на дневную поверхность отсечено от поймы Осереди дамбой полутораметровой высоты. В средней части плотины сделан трубчатый водослив, где и можно измерить мощность родника. Замеры в 1999 году показали, что расход воды в роднике составляет 4,5-5,0 литров в секунду. Вытекающая из разлома вода скапливается в притеррасном понижении на пойме Осереди. Образующийся здесь водоем именуют Крепацким прудом. Водное зеркало пруда почти сплошь прикрыто густой тростниковой зарослью. Из переполняющегося Крепацкого водоема родниковая вода по неглубокому тальвегу перетекает в русло Осереди.
На северной опушке Шипова леса на дне глубокого, метров 25-30, оврага находятся Ливенские ключи. Большой популярностью среди населения пользуются три источника, расположенные цепочкой вдоль тальвега оврага. Самый нижний, что находится ближе к устью, обустроен деревянным лотком и местом для отдыха. Верхний ключ окружен каменным ограждением из гранитных валунов и шокшинских песчаников, оставленных здесь Донским ледниковым языком.

По всему периметру со стороны вершины оврага над ключами нависают пестроцветные неогеновые глины, прикрытые толщей бурой морены. Близость к дневной поверхности глин придает склону неустойчивость. Везде хаотично размещены свежие оползневые блоки. Вот почему добраться до ключей кратчайшим путем нелегко. Натоптанная по крутосклону тропинка из-за подвижек грунта часто разрушается и ее приходится вновь и вновь восстанавливать. В последние годы самый удобный, хотя и более протяженный, подход к Ливенским ключам проложен со стороны устья.

Сочетание чистейшего воздуха, насыщенного фитонцидами Шипова леса, и целебной родниковой воды придает Ливенским ключам особую привлекательность. Пешком и на автотранспорте устраивают к Ливенским ключам паломнические походы жители ближайших сел - Лосева, Ерышовки, Ливенки, Тумановки и даже из райцентра - Павловска. Поговаривают, что на месте Ливенских ключей могут в ближайшие годы устроить оздоровительные процедуры.

\section{ЗАКЛЮЧЕНИЕ}

Родниковые воды Шипова леса - обнадеживающий индикатор, помогающий объяснить естественное произрастание Шиповой дубравы на обводненной ледниковой морене Донского языка.

Конфликт интересов: Автор декларирует отсутствие явных и потенциальных конфликтов интересов, связанных с публикацией настоящей статьи.

Поступила в редакичю 19.01.2021 Принята к публикациии 02.03.2021 


\title{
The Springs in the Shipov Forest
}

\author{
V. I. Fedotov \\ Voronezh state University, Russian Federation \\ (1, Universitetskaya Pl., Voronezh, 394018)
}

\begin{abstract}
The purpose is to acquaint the geographical community and foresters in the Voronezh region with the changes in the water logging content of the forest landscapes of the region on the example of the Shipov forest over the past 160-170 years.

Materials and methods. The published materials in the "Forest Journal" (1887) and the author's field observations have been used in the article.

Results and discussions. It is established that for the last 150-170 years in the Shipov oak forest on the border of the forest-steppe and steppe there were repeated periods of water logging. Periods of high standing of the ground water level contributed to the abundant release of springs. These periods alternated with periods of high-water scarcity and, as a result, the depletion of springs.

Conclusion. The spring waters of the Shipov Forest are a good indicator that can be used to explain the natural growth of oak forests on the northern border of the steppe.
\end{abstract}

Key words: the Shipov Forest, springs, flow rate, water logging, moraine.

For citation: Fedotov V.I. The Springs in the Shipov Forest. Vestnik Voronezskogo gosudarstvennogo universiteta. Seria: Geografia. Geoekologia, 2021, no. 1, pp. 65-68. (In Russ.) DOI: https://doi.org/10.17308/geo.2021.1/3257

Conflict of interests: The author declares no information of obvious and potential conflicts of interest related to the publication of this article.

Received 19.01.2021

Accepted 02.03.2021

Федотов Владимир Иванович

доктор географических наук, профессор кафедры рекреационной географии, страноведения и туризма факультета географии, геоэкологии и туризма Воронежского государственного университета, г. Воронеж, Российская Федерация, ORCID: 0000-0002-2753-4702, e-mail: deanery@geogr.vsu.ru

\section{Vladimir I. Fedotov}

Dr. (Geogr.) Sci., Professor of the Department of Recreational Geography, Country Studies and Tourism, Faculty of Geography, Geoecology and Tourism, Voronezh State University, Voronezh, Russian Federation, ORCID: 0000-0002-2753-4702, e-mail: deanery@geogr.vsu.ru

(C) Fedotov V. I., 2021

$\varangle$ Vladimir I. Fedotov, e-mail: deanery@geogr.vsu.ru

(c) (i) The content is available under Creative Commons Attribution 4.0 License. 